\title{
EFFECT OF NEEM SEED HUSK ASH ON CONCRETE STRENGTH PROPERTIES
}

\author{
S. P. Ejeh ${ }^{1}$, I. Abubakar², A. Ocholi3 ${ }^{3}$, M. M. Nuruddeen ${ }^{4,}$ ". \\ 1, 2, 3, Civil Engineering Department, Ahmadu Bello University, Zaria, NIGERIA \\ 4 Civil EngineEring DePartment, Kano State University of SCIEnCE AND TeChNology, Wudil, NiGERIA
}

E-mail addresses.1 engrdrejeh@yahoo.com,2 idrcivil1@yahoo.com, ${ }^{3}$ amanaocholi@yahoo.com,

4 mnuruddeen@gmail.com

\begin{abstract}
Neem Seed Husk is a by-product obtained during industrial processing of Neem Seed to extract oil and produce fertilizer. Laboratory tests on Neem seed husk ash (NSHA) mixed with cement were conducted to find its effect on concrete strength and workability. Tests including slump test, compressive strength test, concrete density test and scanning electron microscope (SEM) were carried out on concrete partially replaced with $0 \%, 5 \%, 10 \%, 15 \%, 20 \%$ and 25\%NSHA and presented. The test results indicate that concrete workability is affected by NSHA partial replacement by increase in the slump at 5\% and 10\% replacements. But it decreases the slump at 15\%, 20\% and $25 \%$ replacements. At 28 days curing, only the control (0\% replacement) and 5\% replacement satisfied the target compressive strength and therefore can be used for non-structural and mass concrete applications. Densities of most of the cubes partially replaced with NSHA are generally higher than that of the control concrete; this is further supported by the SEM. which indicates that NSHA act as filler and occupy the voids between the aggregates, thereby making the concrete more compact and having higher densities. All the samples have satisfied the density requirement of British standard for normal- weight concrete
\end{abstract}

Keywords: Neem seed husk ash, concrete, slump, compacting factor, compressive, density, scanning electron microscope

\section{INTRODUCTION}

Replacing natural raw materials with wastes may offer a much sought after opportunity to mitigate today's waste management problems. Even if this is done in small amounts, high production rates will translate into significant consumption of waste materials and, for the industry willing to use them, the latter may constitute a cheap and renewable source of raw materials [1].Therefore utilization of waste materials as partial replacement of cement is both technically and economically advantageous for a wide range of applications, including the production of concretes and mortars. In recent years, several studies have confirmed the potential of construction industry as a suitable recipient of various types of recycled wastes, which are now considered secondary raw materials [2]. In third world countries, most of these studies are on agro based wastes, since they are the most common and readily available material with minor economic implications [3]. Waste materials can however only be used in concrete if they are not detrimental to the short- or long- term properties of the concrete [4].
Neem seed husk ash (NSHA) is obtained by burning the waste husk obtained during the extraction of oil from neem seed. Neem seed itself is from Neem tree (Azadirachtaindica) popularly known locally as "Dogonyaro". Earlier research [5] shows that there was synergic effect of NSHA on cement-sand mortar, it also showed the possibility of using it to partially replace cement even though the mortar compressive strength decreases with cement replacement by NSHA.

This research is aimed at investigating the effect of partially replacing cement with $0 \%, 5 \%, 10 \%, 15 \%$, $20 \%$ and $25 \%$ NSHA on concrete strength.

\section{MATERIALS AND METHODS}

\subsection{Materials}

Materials used for this study includes: Ordinary Portland cement, conventional fine and coarse aggregates (sand and gravel) and Neem seed husk ash. Dangote Ordinary Portland cement was used in this study. The cement is in conformity with [6]. River sand obtained locally in Zaria, Nigeria has been used as fine aggregate. The specific gravity of the fine

* Corresponding author, Tel: +234-8037881713 
aggregate was determined to be 2.55 , while its particle size distribution was found to fall within the grading zone 2 of fine aggregates in accordance with [7]. Also, locally available crushed stone aggregate of maximum size $20 \mathrm{~mm}$ was used. The coarse aggregate has a specific gravity of 2.75 .

The Neem seed husk used was obtained from Neem fertilizer processing plant in Katsina, Nigeria. It was dried and burned in an open air, after which it was calcinated in an oven at temperature of $600^{\circ} \mathrm{C}$ to produce Neem seed husk ash. The chemical composition of the Neem seed husk ash was determined using X-Ray Fluorescence (XRF)

\subsection{Mix Proportion}

In this study, concrete to achieve a target compressive strength of $25 \mathrm{~N} / \mathrm{mm}^{2}$ at 28 days was designed using the absolute volume mix design method [8]. Binders were prepared by partially replacing cement with various percentages of Neem seed husk ash (NSHA). The percentages are $0 \%, 5 \%, 10 \%, 15 \%, 20 \%$ and $25 \%$ by weight, with $0 \%$ being the control specimen. For other percentages, cement and NSHA are thoroughly mixed in dry powdered form and in correct proportion. Therefore, for $5 \%$, the cement is partially replaced with 5\% NSHA etc. The binders were then mixed with the aggregates and water in accordance with the mix design proportion to form NSHA concrete.

\subsection{Workability Tests on Fresh Concrete}

Slump test was carried out on fresh concrete with $0 \%$, $5 \%, 10 \%, 15 \%, 20 \%$ and $25 \%$ NSHA replacement. The test was done in accordance [9].

\subsection{Compressive Strength}

Compressive strength test on NSHA concrete cubes produced using steel moulds of size $150 \times 150 \times 150$ mm were carried out. One hundred and eight (108) cube specimens were prepared; they were weighed to determine the density before being tested for compressive strength at $1,3,7,14,28$ and 90 days in accordance with [10].

\subsubsection{Scanning Electron Microscope (SEM)}

The microscopic study of the NSHA paste using scanning electron microscope (SEM) was carried out using JEOL JSM840A scanning electron microscope (SEM). The paste sample used for the SEM was prepared by partially replacing cement with $0 \%, 5 \%$,
$10 \%, 15 \%, 20 \%$ and $25 \%$ NSHA, mixed using watercement ratio of 0.5 and tested after 28 days curing.

\section{RESULTS AND DISCUSSIONS}

\subsection{Materials}

The particle size distributions of fine and coarse aggregates used for the study are shown in Figures 1 and 2. The chemical composition of Neem seed husk ash determined is shown in Table 1.

\subsection{Slump test}

The variation of slump value when cement in the concrete is partially replaced with Neem seed husk ash can be seen in figure 3 . The slump at $5 \%$ and $10 \%$ replacements are higher than that of the control indicating higher workability, with $10 \%$ replacement having the highest workability. While at $15 \%, 20 \%$ and $25 \%$ replacements the slump is lower than the control. This indicates NSHA causes higher demand of water and lower workability at $15 \%, 20 \%$ and $25 \%$ replacements. The NSHA introduced into the cement increases the carbon content due to its high loss of ignition (LOI) and this increases the water required to achieve a reasonable workability. Generally, the slump values ranges from 36 to $40 \mathrm{~mm}$ which falls within the categorization of low workability based on [8].

\subsection{Concrete compressive strength}

Figure 4 shows the result for the compressive strength of concrete partially replaced with Neem seed husk ash at 1, 3, 7, 14, 28 and 90 days.

\subsection{Concrete Density}

Figure 5 shows the result of concrete density test.

\subsection{Scanning Electron Microscope (SEM) test}

The result of SEM test is shown in Plates I to VI.

Table 1: Chemical Composition of Neem seed husk ash

\begin{tabular}{cc}
\hline Oxide & \% of Neem Huskash \\
\hline $\mathrm{Al}_{2} \mathrm{O}_{3}$ & 3.00 \\
$\mathrm{SiO}_{2}$ & 25.40 \\
$\mathrm{CaO}$ & 32.90 \\
$\mathrm{Fe}_{2} \mathrm{O}_{3}$ & 8.68 \\
$\mathrm{~K}_{2} \mathrm{O}$ & 14.30 \\
$\mathrm{MnO}$ & 0.18 \\
$\mathrm{MgO}$ & 2.00 \\
$\mathrm{SO}$ & 4.42 \\
$\mathrm{Na}_{2} \mathrm{O}$ & 0.20 \\
$\mathrm{LOI}$ & 9.03 \\
\hline
\end{tabular}




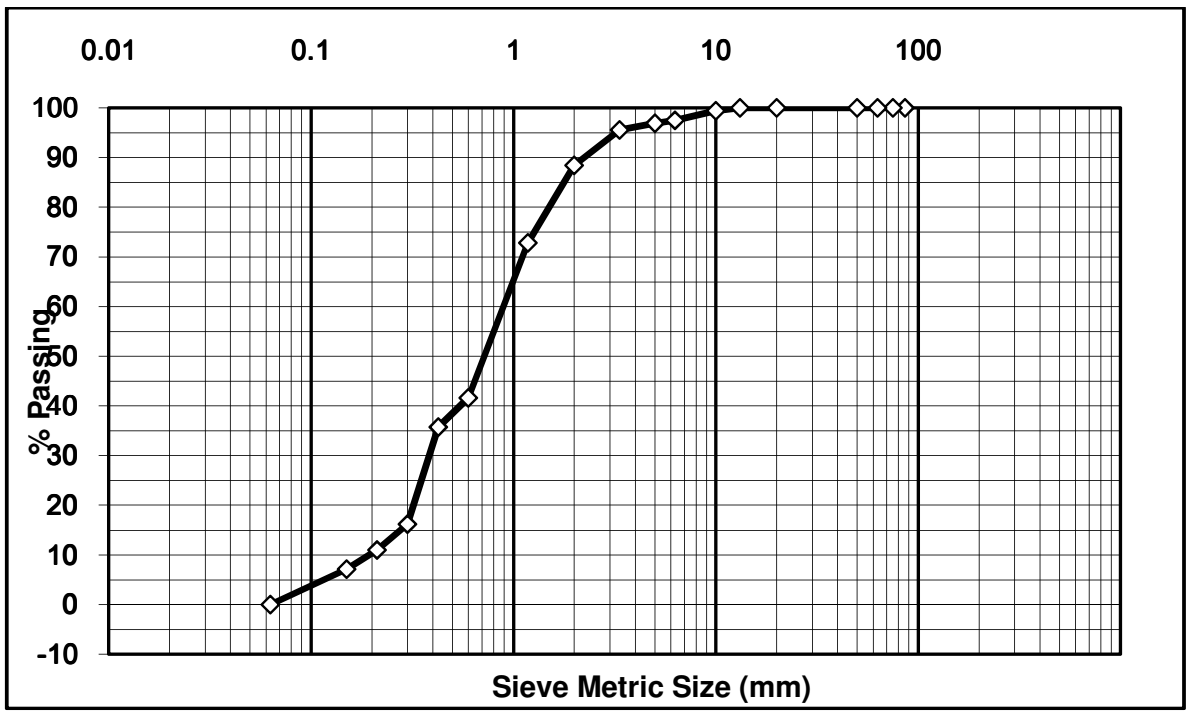

Figure 1: Particle size distribution of the Fine aggregate

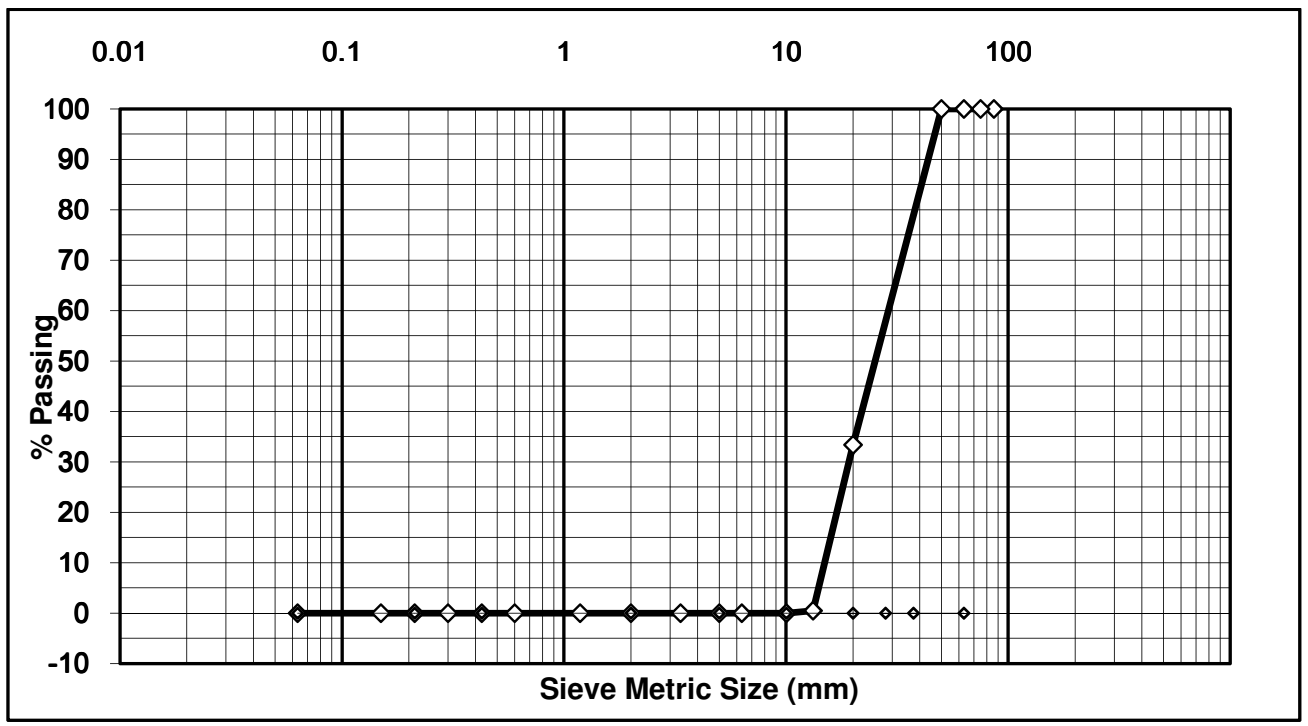

Figure 2: Particle size distribution of the coarse aggregate

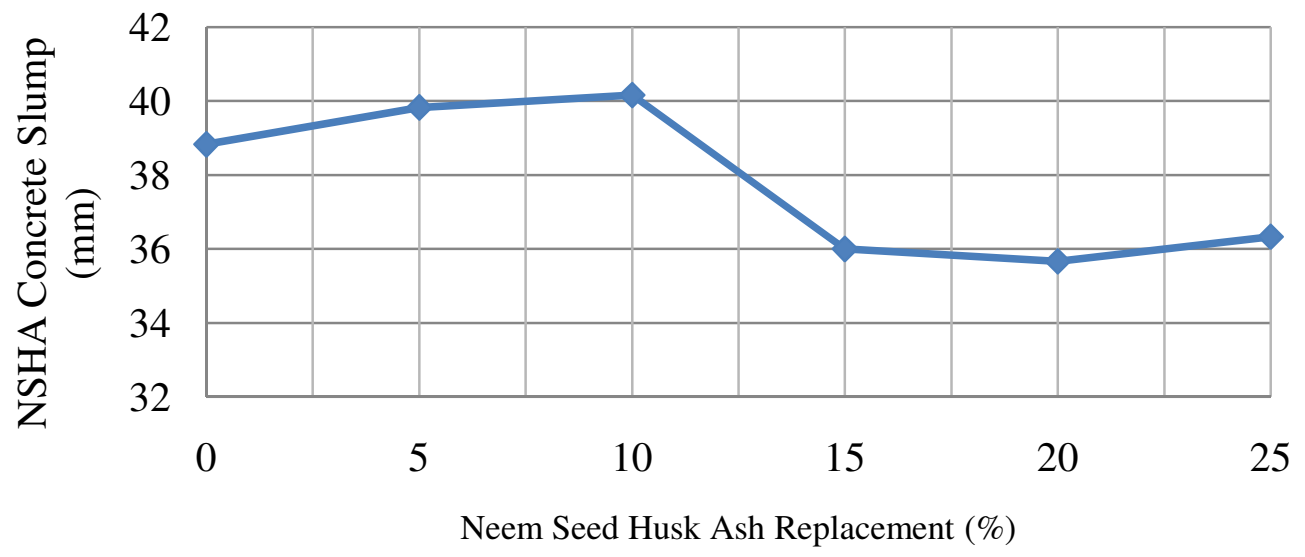

Figure 3: Concrete slump against various percentage replacement of NSHA 


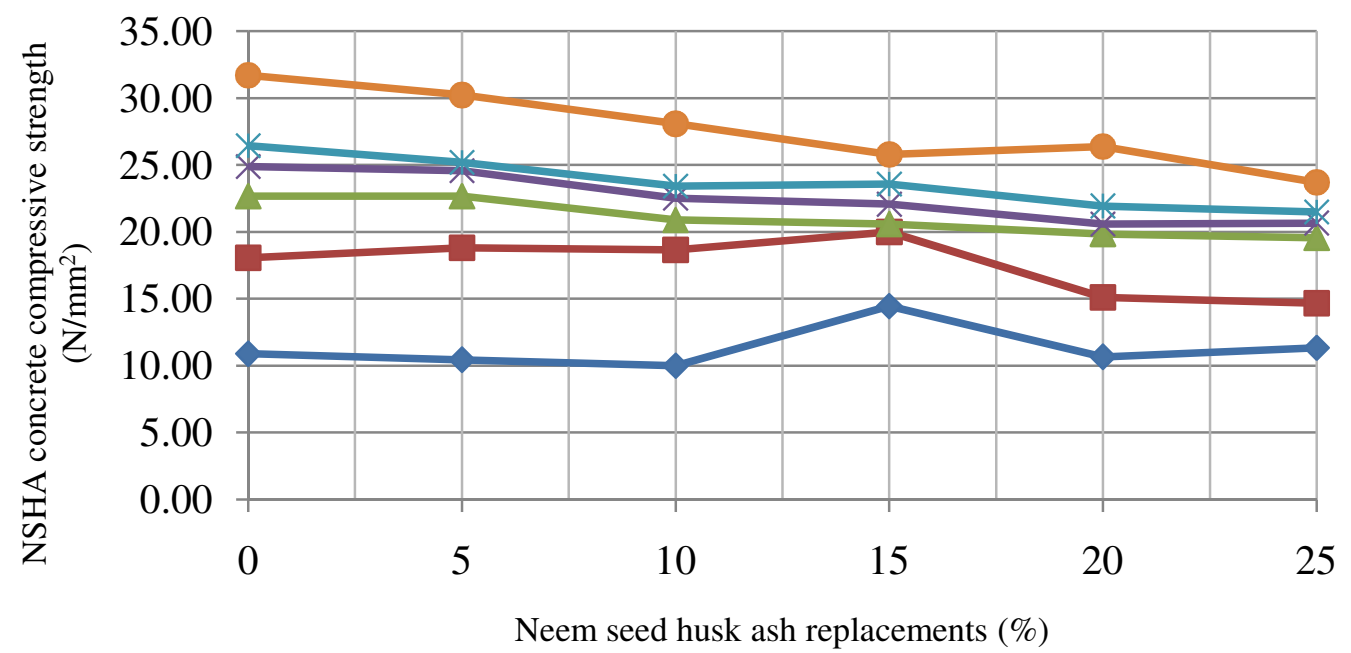

$\neg 1$ day $\leftarrow-3$ days $\leftarrow 7$ days $\longleftarrow 14$ days $* 28$ days $\multimap-90$ days

Figure 4: compressive strength against various percentage replacement of NSHA



Figure 5: Result of concrete density test

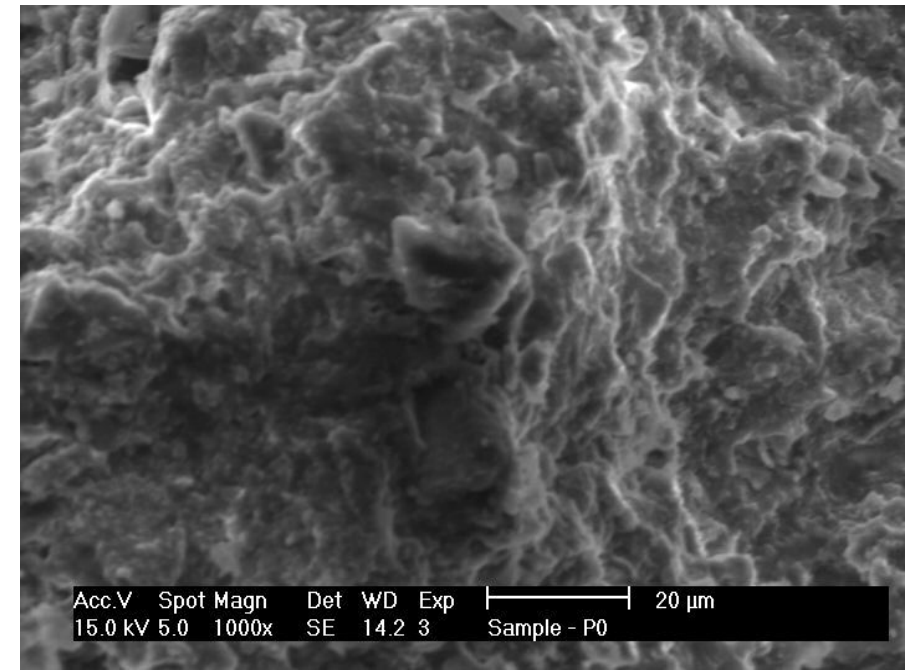

Plate I: Paste replaced with O\% NSHA

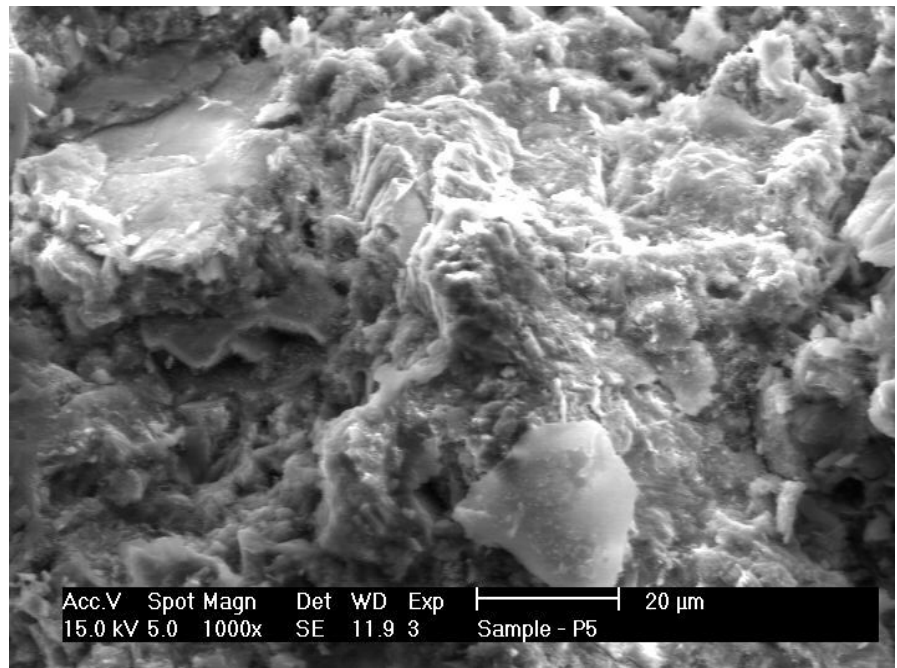

Plate II: Paste replaced with 5\% NSHA 


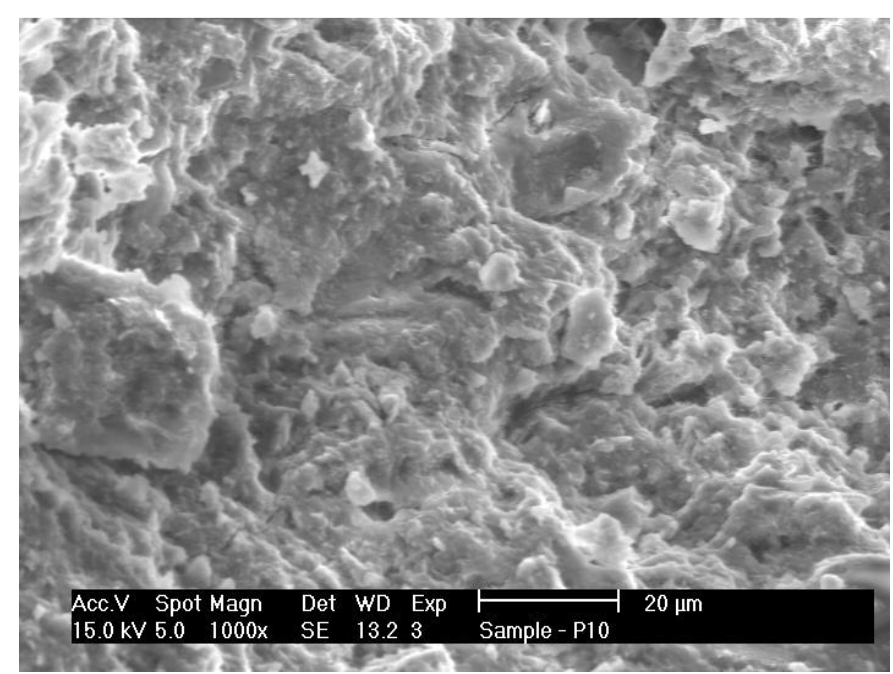

Plate III: Paste replaced with 10\% NSHA

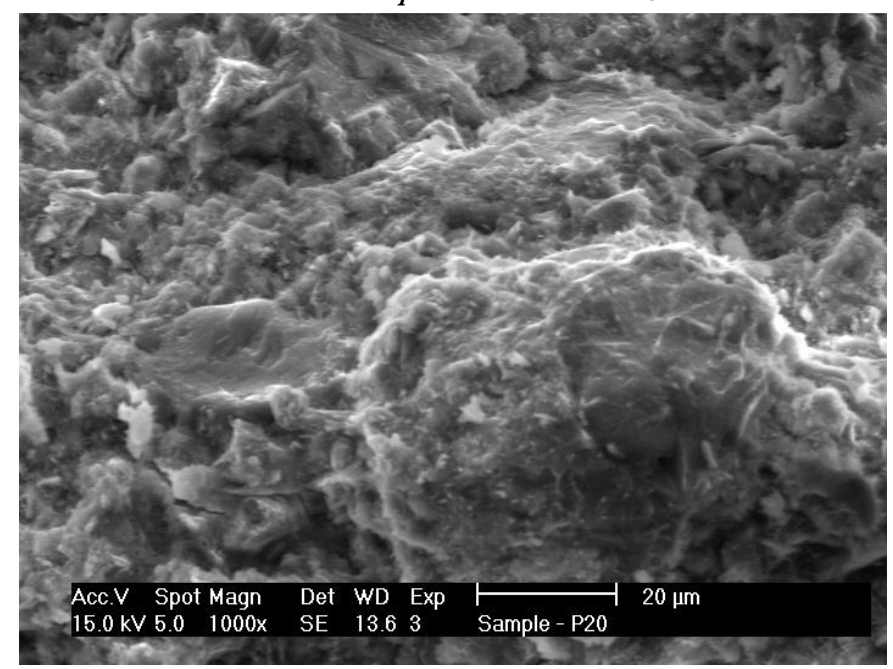

Plate V: Paste replaced with 20\% NSHA

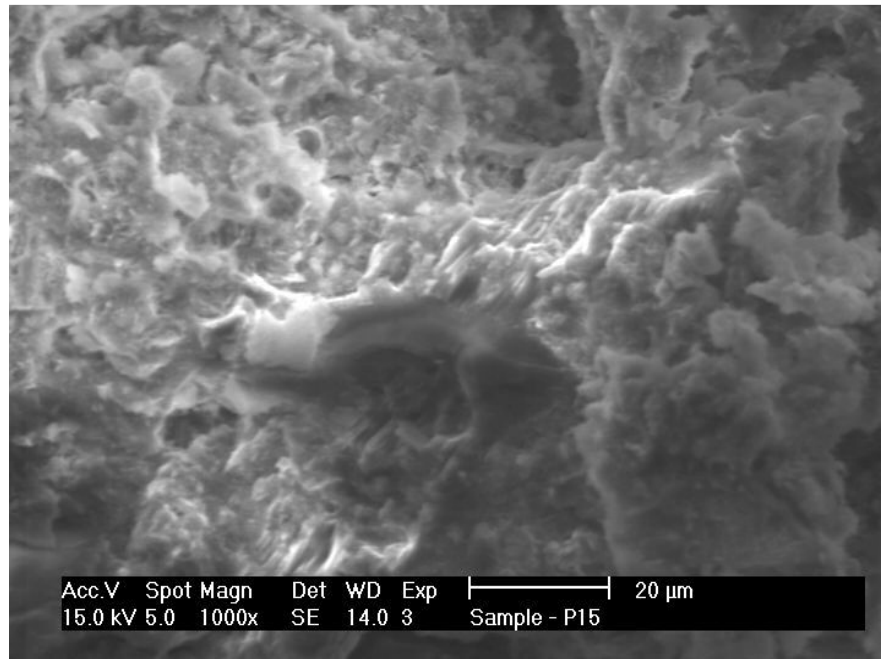

Plate IV: Paste replaced with 15\% NSHA

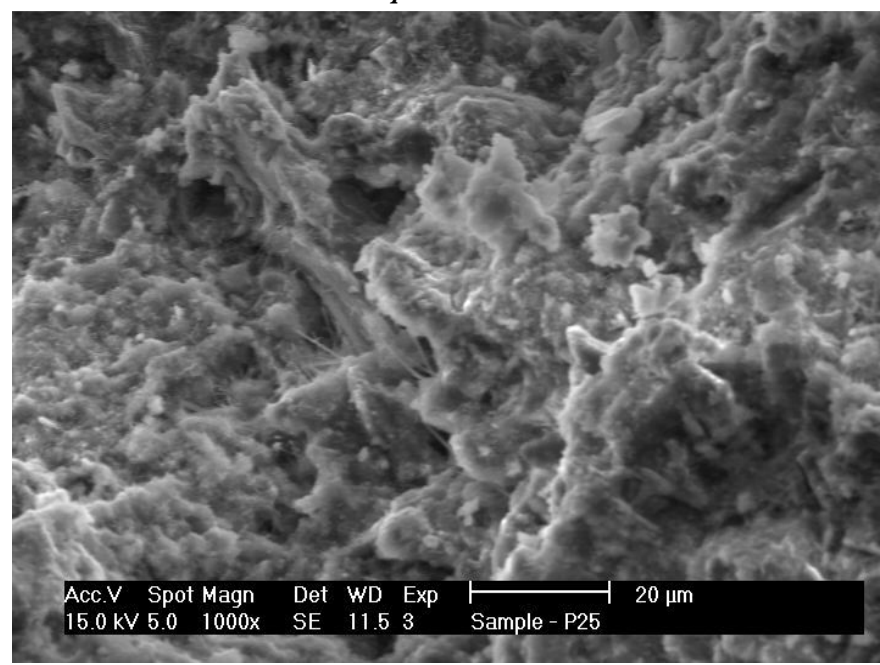

Plate VI: Paste replaced with 25\% NSHA

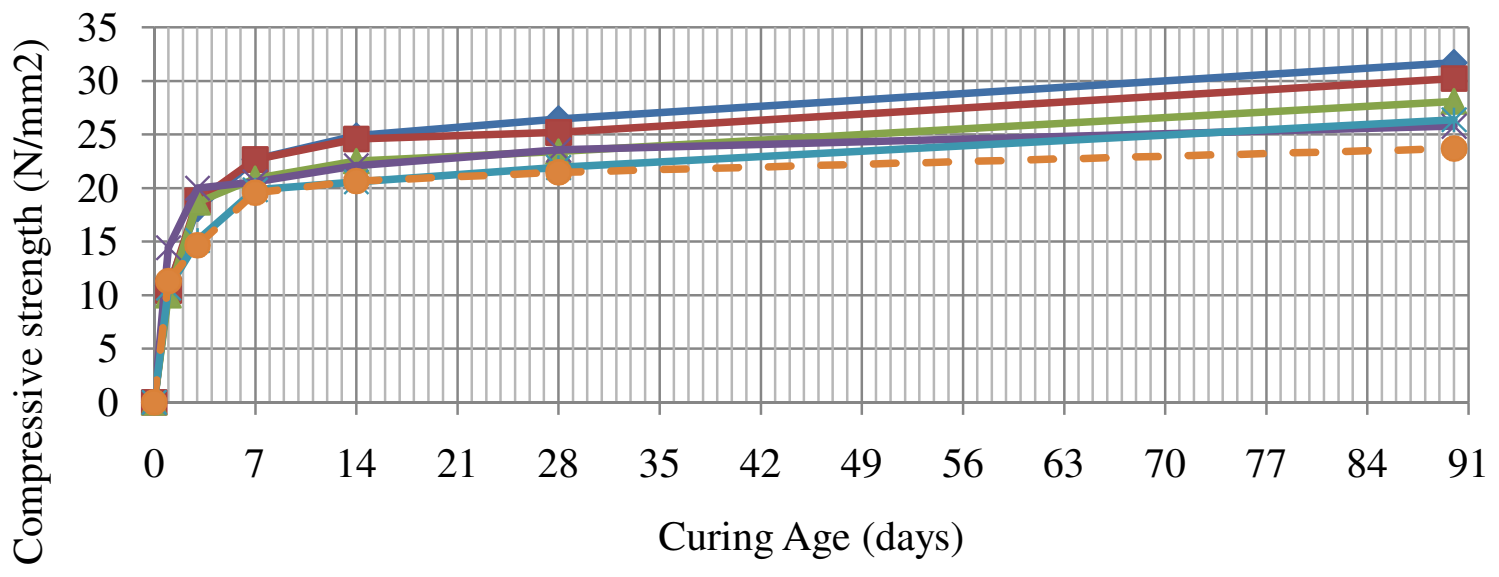

$-0 \%$ Replacement $-5 \%$ Replacement $-10 \%$ Replacement $\leftarrow 15 \%$ Replacement $\rightarrow-20 \%$ Replacement $-\odot-25 \%$ Replacement

Figure 6: NSHA compressive strength development at various replacements

\subsection{Concrete compressive strength}

From Figure 4, the compressive strength increases with age but decreases with NSHA content. The decrease in strength with increase in NSHA content can be explained from the reduction of the quantity of cement and by implication $\mathrm{CaO}$ in the mix. Since, the $\mathrm{CaO}$ of NSHA is not as high as that of cement; the $\mathrm{C}_{3} \mathrm{~S}$ will be lower in the mix containing the NSHA. Also, at 
28 days, only the control ( $0 \%$ replacement) and 5\% replacement have satisfied the target designed compressive strength of $25 \mathrm{~N} / \mathrm{mm}^{2}$. However, all the samples have attained the compressive strength of 20 $\mathrm{N} / \mathrm{mm}^{2}$ at 28 days; therefore they can be used for nonstructural and mass concrete applications.

Figure 6 shows the compressive strength development of NSHA concrete over a curing period of $1,3,7,14,28$ and 90 days.

From figure 6 , it can be seen that there is increased strength development, and the compressive strength increases with curing time and decreases with cement replacement by Neem seed husk ash. It can be seen that there is rapid rate of increase at the initial stage which is followed by a gradual diminishing rate with time, forming the usual concrete strength development parabolic curve. It can be deduced that in the first three days, the strength development is faster in samples with Neem ash replacement than the control sample. But, after 14 days, the control sample strength development becomes higher than samples with the replacements.

\subsection{Concrete Density}

It can be generally observed from Figure 5 that the densities are generally higher at the early age, after which they gradually reduce. Also most of the concrete partially replaced with NSHA are having higher density than the control. Normally, as concrete hardens it uses up water in hydration, and the products of hydration occupy less space than the original water and cement [8]. Therefore, after 28 days curing, the hydration is generally stable and the densities are lowest as most of what is remaining is the hydration products with only little quantity of unhydrated cement. From the SEM (shown in plates I to VI) it can be observed that pastes partially replaced with NSHA are denser than the control. The unhydrated Neem seed husk ash (which can be identified by their characteristic brightness in the SEM) act as a filler and occupy the voids between the aggregates, thereby making the concrete more compact and having higher densities.

The 28 days concrete density as presented in Figure 5 when compared with the recommendations of [11] which stipulate minimum density of $2000 \mathrm{Kg} / \mathrm{m}^{3}$ and maximum of density of $2600 \mathrm{Kg} / \mathrm{m}^{3}$ for normalweight concrete, it can be concluded that all the samples are normal- weight concrete.

\section{CONCLUSIONS}

Based on the test results and discussions, the following conclusion can be drawn:

1. Neem seed husk ash replacement increases the slump at 5\% replacement and 10\% replacement. But it decreases it at $15 \%, 20 \%$ and $25 \%$ replacements. The NSHA introduced into the cement increases the carbon content due to its high loss of ignition (LOI) and this increases the water required to achieve a reasonable workability.

2. Neem seed husk ash replacement in concrete increased the compressive strength with curing time and decreases it with increase in percentage replacement by Neem seed husk ash. After 28 days curing, only the control ( $0 \%$ replacement) and $5 \%$ replacement have satisfied the target designed strength of $25 \mathrm{~N} / \mathrm{mm}^{2}$. However, all the samples have attained the compressive strength of $20 \mathrm{~N} / \mathrm{mm}^{2}$ at 28 days; therefore they can be used for non-structural and mass concrete applications.

3. Effect of Neem seed husk ash on concrete density shows that densities are generally higher at the early age, after which they gradually reduce. Also, the densities of most of the cubes partially replaced with NSHA are generally higher than that of the control concrete; this is further supported by the SEM, which indicates that NSHA act as filler and occupy the voids between the aggregates, thereby making the concrete more compact and having higher densities. All the samples have satisfied the requirement of British Standard for normal- weight concrete.

\section{REFERENCES}

1. Daniel V. R., João A.L.and Marcio R. M., "Potential Use of Natural Red Mud as Pozzolan for Portland Cement", Materials Research Journal. 2011; Vol14 (1): pp 60-66

2. Tay, G. H, and Show K. Y., "Use of ash Derived from Oil Palm Waste Incineration as a Cement Replacement Material", Journal of Resources, Conservation and Recycling, Vol. 13, 1995, pp 2736.

3. Menassah J., "A Review of Partial Replacement of Cement with Some Agro Wastes", Nigerian Journal of Technology, Vol. 29 No 2, June 2010: PP12-20

4. Siddique R., Waste Materials and By-Products in Concrete, Springer-Verlag Berlin Heidelberg. 2008

5. Nuruddeen M.M and Ejeh S.P., "Synergic Effect of Neem Seed Husk Ash on Strength Properties of Cement-Sand Mortar" International Journal of 
Engineering Research and Applications (IJERA) ISSN: 2248-9622 www.ijera.com Vol. 2, Issue 5, 2012, pp.027-030

6. BS EN 197-1:2000, Cement: Part 1: Composition, specifications and conformity criteria for common cements", British Standards Institute, 389 Chiswick High Road, London, W4 4AL, http://www.bsiglobal.com/.2000

7. BS 882-1983, Aggregates from natural Sources for concrete, British Standards Institute, 389 Chiswick High Road, London, W4 4AL, http://www.bsiglobal.com/.1983

8. Neville, A. M., Properties of Concrete, Third edition Pitman Publishing Co., London. 1981
9. BS 1881-102:1993, Testing Concrete: Part 102. Method for determination of slump, British Standards Institute, 389 Chiswick High Road, London, W4 4AL, http://www.bsi-global.com/.1993

10. BS 1881-116:1983, Testing Concrete: Part 116. Method for determination of compressive strength of concrete cubes, British Standards Institute, 389 Chiswick High Road, London, W4 4AL, http://www.bsi-global.com/.1993

11. BS EN 206-1:2001, Cement: Part 1: Specification, performance, production and conformity, British Standards Institute, 389 Chiswick High Road, London, W4 4AL, http://www.bsi-global.com/.2001 